\title{
Retraction: Prospects and applications of nanobiotechnology: a medical perspective
}

\author{
Md Fakruddin ${ }^{1 *}$, Zakir Hossain ${ }^{1}$ and Hafsa Afroz ${ }^{2}$
}

\begin{abstract}
This article [1] is retracted as it contains large amount of text that has been duplicated from other articles previously published. We apologize to all affected parties for the inconvenience caused.
\end{abstract}

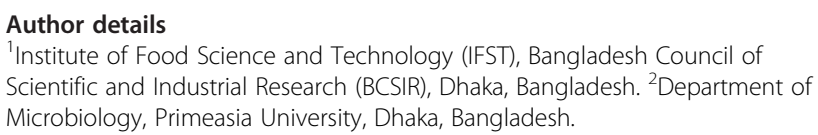

'Institute of Food Science and Technology (IFST), Bangladesh Council of Scientific and Industrial Research (BCSIR), Dhaka, Bangladesh. ${ }^{2}$ Department of Microbiology, Primeasia University, Dhaka, Bangladesh.

Received: 14 August 2012 Accepted: 4 October 2012

Published: 4 October 2012

\section{Reference}

1. Fakruddin M, Hossain Z, Afroz H: Prospects and applications of nanobiotechnology: a medical perspective. J Nanobiotechnol 2012, 10 (1):31.

- Convenient online submission

- Thorough peer review

- No space constraints or color figure charges

- Immediate publication on acceptance

- Inclusion in PubMed, CAS, Scopus and Google Scholar

- Research which is freely available for redistribution 